\title{
Theological Issues that Arise Out of Odwira Sacrifices
}

\author{
Ernestina Afriyie ${ }^{1}$ \\ ${ }^{1}$ Akrofi-Christaller Institute of Theology, Mission and Culture, Akropong-Akuapem Ghana.
}

\begin{abstract}
Some Christians claim that after the sacrifice of Jesus Christ on the cross, the ultimate sacrifice; no other sacrifice is needed by the Christian. This paper examines some of the sacrifices made as part of the celebration of the Okuapehene Dwira(Odwira), a festival celebrated by the Akuapem of Ghana. It looks at how the sacrifices are made and their significance. It also examines theologically the sacrifice of Christ and what it has achieved for the believer. The paper is based on observations of the festival, interviews with traditional leaders as well as the ordinary people in Akropong. Responses given to a questionnaire on the festival by indigenes of Akuapem living in Akropong and around Sakumono and Lashibi in the Greater Accra Region are also used. In addition, commentaries, and writings on sacrifice by theologians are analysed and used. The study's findings indicate that even though the sacrifices involved in the Odwira festival are not propitiatory sacrifices like that of Christ, the sacrifice of Christ has currently rendered all of them unnecessary. The paper contributes to scholarship by affirming what some theologians have already put forward, that the sacrifice of Jesus is the ultimate blood sacrifice after which no other sacrifice is needed. The paper falls under the disciplines of theology, religion, culture, and Gospel and Culture.
\end{abstract}

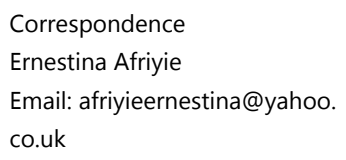

co.uk

Publication History

Received 28th August, 2020,

Accepted 4th September 2020,

Published online 17th September 2020.

Key words: sacrifice, mediators, Nananom Nsamanfo, abosom, Odwira.

(C) 2020 The Authors. Published and Maintained by Noyam Publishers.

This is an open access article under the CCBY license (http://creativecommons.org/licenses/by/4.0/).

\section{INTRODUCTION}

Sacrifice is a worldwide phenomenon. According to Awolalu, throughout history, the practice of sacrifice has been encountered whenever human beings have worshipped divine beings. ${ }^{2}$ The truth of this statement is affirmed in writings on sacrifices among different African peoples. Ukpong, for example, has an article on the place of God in sacrifice in African Traditional Religion (ATR). ${ }^{3}$ The article shows that sacrifice is part of ATR. C. R. Gaba has also written on Sacrifice in Aylo religion. In his article, he makes the point that the Aylo people perform "sacrifice on many occasions." Der also writes about sacrifice among the Kasena and Dagaba of Northern Ghana. ${ }^{5}$ Idowu opines that sacrifice is of the essence of every religion that the world has known. ${ }^{6}$ That is to say that sacrifice forms part of every religion in the world. Bringing this point home, Mbiti has also said that it constitutes "one of the commonest acts of worship in Africa."

The Christian faith stands on a sacrifice - the sacrifice of Jesus Christ for the salvation of humanity. Christians believe that this sacrifice is the ultimate blood sacrifice; it cancels all other blood sacrifices. Everything that human beings offer sacrifices for has been catered for in the sacrifice of Jesus Christ. One of the African theologians who hold this view is Olowola. He says that the teaching of the New Testament (NT) is that Jesus Christ "has been made the final sacrifice for sin once for all. Any further sacrifice, whether to spirits or even to God himself, is therefore to be

\footnotetext{
Omosade Awolalu, Yoruba Beliefs and Sacrificial Rites, (Essex, UK: Longman, 1979), 136.

Justin S. Ukpong, "The Problem of God and Sacrifice in African Traditional Religion," Journal of Religion in Africa, XIV, fasc 3, (1983), 187 - 203.

C. R. Gaba, "Sacrifice in Aylo Religion, Part I," The Ghana Bulletin of Theology, 3, no.5, (1968), 13.

B. G. Der, "God and Sacrifice in the Traditional Religions of the Kasena and Dagaba of Northern Ghana," Journal of Religion in Africa, XI, 3 , (1980),172 - 187.

Bolaji Idowu, Olódùmarè, God in Yoruba Belief, (Brooklyn, New York: A\&B Books Publishers, 1994), 118.

John S. Mbiti, African Religions and Philosophy, (Oxford: Heinemann, 1990), 58.
} 
eliminated." Some elders of Okuapeman however claim that the sacrifices involved in the celebration of the festival do not duplicate or challenge that of Jesus Christ and so Christians do not need to worry about them. ${ }^{9}$ This paper which seeks to show that the sacrifice of Jesus Christ has fulfilled the purpose of all sacrifices, begins by attempting a definition of sacrifice, and then discusses the different types of sacrifices that exist. This is followed by some information on who the Akuapem people are and how they started celebrating the festival. Next, the paper describes the various sacrifices made during the festival. Here, the significance of each sacrifice is discussed to tell whether the sacrifice is a votive, propitiatory, preventive, thanksgiving, substitutionary, or any other one. The paper also looks at the sacrifice of Christ, its meaning and significance, and then deliberating on whether this sacrifice supersedes and so renders all other sacrifices unnecessary or not.

\section{A definition of sacrifice}

There are two ways in which the word "sacrifice" may be understood. First, when something is given up for another thing to be achieved, the act is a sacrifice. Thus, a person may give up certain comforts and pleasures to ensure that s/he pays for his/her education. Such a person sacrifices these comforts and pleasures for his/her education. In the same way, to use an example given by Awolalu, a teacher who stays on after school to help weaker students in his/her class to catch up with the rest of the class without taking any remuneration, can also be said to be making a sacrifice. ${ }^{10}$

Sacrifice is also used to refer to the giving up of costly things to achieve something in relation with the supernatural. A person may offer an animal, or certain items, so that his/her relationship with the divinities may be strengthened. People may also give offerings to divinities to receive healing from sicknesses and diseases or obtain some other favours. It is such sacrifices that this paper is about.

Sacrifice has been defined in various ways by various theologians. James, based on the purposes of sacrifices, defines sacrifice as that which

involves the destruction of a victim 'for the purpose of maintaining or restoring a right relationship of man to the sacred order. It may effect a bond union with the divinity to whom it is offered or constitute a piacular expiation to 'cover,' 'wipe out', neutralize or carry away evil guilt contracted wittingly or unwittingly.' ${ }^{11}$

The Encyclopedia of Religion and Ethics, also defines sacrifice as

a rite in the course of which something is forfeited or destroyed, its object being to establish relations between a source of spiritual strength and one in need of such strength, for the benefit of the latter. ${ }^{12}$

Both definitions, show that a sacrifice always involves the giving away or destruction of something for a spiritual purpose. The one who makes the sacrifice benefits from it. James uses the term "sacred order" and the Encyclopedia of Religion and Ethics uses "source of spiritual strength". Both expressions refer to the supernatural.

\section{Types of sacrifices}

The animal used for sacrifice depends on the kind of sacrifice being made, that is, the purpose, as well as the spiritual being to whom it is being made. This means that a sacrifice is not just the killing of an animal but killing it for a spiritual purpose. When a man slaughters a chicken to feed his family, it is not a sacrifice; it is only when he slaughters the chicken for a divinity to achieve something from the divinity, that the slaughtering can be called a sacrifice. Sacrifice is a physical act for a spiritual reason. According to De Vaux, "sacrifice is the essential act of external worship", an acted prayer, a symbolic action expressing the interior feelings of the one offering it, as well as the response of the supernatural to the prayer. He stresses this point by saying that there are many motives for sacrifices. ${ }^{13}$ The motive determines the type of sacrifice that is made. People offer animals or other things like vegetables, eggs, grains, or drinks to supernatural spirits as sacrifices for various reasons. Mbiti however opines that offerings of animals, those which involve blood, are what are called sacrifices, while those that do not involve blood are offerings; so that for him, a sacrifice is when an animal is killed. ${ }^{14}$

The reason for making a sacrifice, as has already been stated, determines the kind of sacrifice made and the elements presented. Another thing that determines what victim is offered, is the supernatural being to which it is offered. Different supernatural beings have different preferences; some prefer sheep, some prefer chickens, some dogs and so on.

\footnotetext{
8 Cornelius Olowola, "Sacrifice in African Tradition and in Biblical Perspective", Africa Journal of Evangelical Theology, 10, 1, (1991), 5.

9 This is the view of the late Jkoman Panyin Barima Akyeampong (Interviewed on August 18, 2003), Nana Afari Bampo II, Banmuhene (Interviewed on Friday, October 22, 2004) and the late Nana Addo Panyin, Adumhene (Interviewed on March 4, 2008).

10 Awolalu, Yoruba Beliefs and Sacrificial Rites, 134.

1 E. O. James, in Awolalu, Yoruba Beliefs and Sacrificial Rites, 135 - 136.

2 James Hastings (Ed.), Encyclopedia of Religion and Ethics vol.11, (Edinburgh: T. \& T. Clark Ltd, 1980), 1.

3 Roland De Vaux, Ancient Israel Its Life and Institutions, (London: Darton, Longman \& Todd, 1978), 451.

4 Mbiti, African Religions and Philosophy, 58.
} 
This accounts for the fact that there are different types of sacrifices. Idowu puts the types of sacrifices under about six different categories. According to him, a sacrifice may be a gift or a thank-offering, it may be a votive offering, or be for propitiation, or for prevention. It may also be a substitutionary sacrifice..$^{15}$ This paper continues with a description of each type.

\section{Thanksgiving sacrifice}

A thanksgiving sacrifice is one made for a favour received from a supernatural being, to whom the devotee makes a request. When the request is granted, the devotee may take a gift to the divinity to thank him/her for granting the request. Sometimes, a person may unexpectedly receive a favour from the divinity; a thanksgiving sacrifice may also be made for this. It serves as a means of showing gratitude. Among the Yoruba, thanks-giving sacrifices are also communion sacrifices as they are accompanied by feasting. The Aylo of Ghana call such a sacrifice, dzatutu.

\section{Votive sacrifice}

A votive sacrifice is one made in fulfilment of a vow. A devotee of a divinity may present a request to the divinity and promise to give something back to the divinity when his/her request is granted. The offering made when the request is granted, is a votive sacrifice. It is a thanksgiving sacrifice but differs from a normal thanksgiving sacrifice in that the offering is made in fulfilment of a promise by the devotee. It is therefore a sacrifice used to fulfil a vow. In Judges 11, there is an example of a votive sacrifice. Jephthah promised God that if He gave him victory in the war he would offer the first thing he saw on his return home to God as a sacrifice. Jephthah won the battle. When he returned home, his only child, a daughter, came out with a tambourine to meet him. As Jephthah had made a promise, he made a votive sacrifice of his daughter to God.

\section{Propitiatory sacrifice}

When a sacrifice is made to appease a divinity, who may have been offended or angered by a community or devotees, it is called a propitiatory sacrifice. It is made to win back the favours of the divinity.

\section{Preventive sacrifice}

A preventive sacrifice has to do with making a sacrifice to ensure that one, or the community, is kept safe from evil and misfortune. This type of sacrifice comes out of the belief that the world is populated by spirits, some good, and some evil. The evil spirits seek to harm people and communities; sacrifices remove the harm and evil. A preventive sacrifice is a precautionary measure that is taken to prevent an imminent danger or harm.

\section{Substitutionary sacrifice}

In a substitutionary sacrifice, an animal is offered in place of a person. Such a sacrifice is usually performed in what is known among the Akan of Ghana as musuyi. Here, if for example a child is sick, a relative of the sick child, usually the father, takes him/her deep in the night to a junction with a liquid concoction made from water and special leaves, and a chicken which is a few days old. The child is bathed with the concoction. Then the father holds the chicken by the legs and swings it three times over the head of his child while praying and making incantations for the chicken to die in the place of his child. After the third swing, the father throws the chicken hard on the ground so that it dies. Then father and child turn around and go quickly back home without looking back. The life of the chicken in this instance, is exchanged for that of the human being; it is given to the evil spiritual beings responsible for making the child ill.

\section{The Akuapem people and the genesis of Odwira}

Having considered the different types of sacrifices, the author now considers the sacrifices involved in the celebration of Odwira so the types of sacrifices here can be known; but as this paper is based on the Odwira festival celebrated by the Akuapem, it is expedient to introduce the people and how the celebration of the festival began. The Akuapem state is in Ghana, a country in West Africa. It is situated between longitude $0^{\circ} 15 \mathrm{~W}-0^{\circ} 00$ and latitude $5^{\circ} 45-6^{\circ} 00 \mathrm{~N}$. Once every year the Okuapehene (the paramount chief of the Akuapem state) leads his people to celebrate the festival known as Okuapehene Dwira (Odwira) in Akropong, the capital of the Akuapem state. There are over seventeen (17) towns forming the state. These include Berekuso, Aburi, Ahwerease, Obosomase, Tutu, Mampong, Amanokrom, Mamfe, Larteh Ahenease, Larteh Kubease, Akropong, Abiriw, Dawu, Awukugua, Adukrom and Apirede.

The people began celebrating the festival in 1826. According to history, during the war which was fought by a

\footnotetext{
15 Idowu, Olódùmarè, God in Yoruba Belief, 121 - 125.
} 
coalition of Akuapem, Akim, Fante, Ga, Adangme, Akwamu the British and the Danes against Asante at Katamanso, ${ }^{16}$ a native of Jbosomase, a town in Akuapem, captured a regalia which the Akuapem call the Odosu, along with an elderly woman who was attending to it from the Asante warriors, and brought them to Akropong. This is stated in the account of the war by Kwamena-Poh, ${ }^{17}$ but he does not call what was captured Odosu. He states that the head of the late Governor, Sir Charles Macarthy which Asante had taken in 1824, fell into the hands of Nana Addo Dankwa, the Okuapehene. ${ }^{18}$ The people of Akuapem say that the Odosu is made up of the skulls of great kings defeated by Asante in their various wars. They mention specifically the skull of Sir Charles Macarthy. The tradition goes on that the woman captured with the regalia, told the Ômanhene of Akuapem that in order for Akuapem to benefit from the presence of the Odosu in their state, they would have to celebrate the Odwira annually. Further information on the history of the celebration given by Nana Addo Birinkorang, Apesemakahene (chief spokesman of the chief), says that the Akuapem warriors who fought in the Katamanso war returned to Akuapem on August 11, 1826. ${ }^{19}$ On August 16, 1826, the Jman (state) led by the Jmanhene, who is the Okuapehene, held spiritual consultations under the Mpeni tree in Akropong on the Odosu. On August 25, 1826, they performed rites to purify the Jman after the war. That same day, during the purification ceremonies, they held consultations and took the decision to make Odwira an annual Akuapem Festival. Ever since that day, the people have celebrated the festival every year.

This festival is important to all who come from Akuapem. Some people who come from Akuapem and are Christians however are faced with a dilemma when it comes to celebrating it. Responding to a questionnaire asking questions like; Should the people of Akuapem continue celebrating Odwira? If yes, why? If no, why? Akuapem Christians made it clear that they would like the celebration to continue. ${ }^{20}$ They gave as some of the reasons for wanting the celebration of the festival to continue the fact that it gives them the opportunity to celebrate their culture, their heritage and their tradition, it brings about the connection of families, and they make the sense of community strong. They however indicated that when they celebrate it, they feel guilty and when they do not celebrate it, they feel guilty. One of the reasons they gave for this feeling, is the subject of this paper.

\section{METHODOLOGY}

This paper is based on observations of the Okuapehene Dwira over a period of six years. During this period, the writer interviewed some traditional leaders of Akuapem like the Okuapehene Nana Addo Dankwa III, the Banmuhene, Nana Kwame Afari Bampo II, the Akuapem Gyaasehene Nana Osim Kwatia, Jkoman Panyin Barima Akyeampong, Owura Kwame Bekoe, the Akuapem State secretary, and a few others. Ordinary members of the community, traditional religious leaders, and Christian leaders were also interviewed. These interviews were recorded, with the permission of those interviewed, and transcribed. Questionnaires were also administered to eighty (80) Akuapem Christians who live in Akropong, Sakumono and Lashibi in the Greater Accra Region to find out their views on the celebration of the festival, whether they would like the celebration to continue or not, and whether they had any religious or theological issues with it. Of the eighty, only fifty-two (52) people filled out the questionnaire and returned them. The responses were analysed to determine what theological issues Akuapem Christians have with the celebration of the festival.

\section{FINDINGS}

While all the people interviewed, as well as the fifty-two who responded to the questionnaire were of the view that the celebration of the festival should continue, those who identified themselves as Christians said that they had issues with the presence of sacrifices in the festival. All the fifty-two (52) who responded to the questionnaire and returned them indicated among other things that the blood sacrifices made in the celebrations is something that makes them uncomfortable with the celebration. They all gave as their reason for being uncomfortable with the sacrifices the fact that they challenge the sacrifice of Jesus Christ. According to them all, after the sacrifice of Christ, no other blood sacrifice is needed; it is a sacrifice that serves all the purposes for which human beings offer sacrifices.

\section{DISCUSSION}

The discussion first and foremost focuses on the sacrifices that are performed during the festival, and then the sacrifice of Jesus Christ.

\footnotetext{
16 Katamanso is a town on the Accra Plains, near Dodowa. Sometimes it is called Akatamansu; M. A. Kwamena-Poh, "History," in David Brokensha (Ed.), Akwapim Handbook, (Accra - Tema: Ghana Publishing Corporation, 1972), 45.

17 Kwamena-Poh, "History", 45.

18 Ibid.

19 Nana Addo Birikorang, "Akuapem Odwira - Adaebutuw Festival", Akuapem Odwira and Adae Butuw Festivals - Odwira Souvenir Brochure, 1998, 2. Nana Addo Birinkorang was the Apescmakahene of Akropong.

20 All the Christians who were interviewed, as well as those who responded to the questionnaire, said that they would want the celebration to continue.
} 


\section{The Sacrifices of Odwira}

One of the things that characterise the celebration of Odwira is sacrifices. Several sacrifices are made at different places at different times during the festival. This section describes and discusses some of the sacrifices made during Odwira. They are discussed in a chronological order.

\section{a. Sacrifice at pow mu on Odwira Tuesday}

On Odwira Tuesday, when the team led by the Banmuhene (chief custodian of the royal mausoleum) and Adumhene (chief executioner) go to $p$ эw mu (royal mausoleum) to bring Nananom Nsamanfo (royal ancestors) and Odwira home, they take with them, some palm wine, bottles of schnapps, some tubers of yam, and two sheep. When they arrive, they observe protocols with the people who live in Amanprobi. ${ }^{21}$ Then the Banmuhene, pours libation with the drinks, the palm wine first and then the schnapps. He informs Nananom Nsamanfo of their reason for being in Amanprobi - that the time for celebrating the Okuapehene Dwira has come and they have been sent to bring Nananom Nsamanfo home. He mentions the items that Okuapehene has asked them to bring to Nananom Nsamanfo. After the prayer, he slaughters one of the sheep, spills the blood, and throws the carcass over his head so it falls behind him. The meat from this carcass is used to prepare a meal which all the people present eat. The second sheep is sacrificed at $p э w m u$, the part of the cemetery where the graves of Nananom (the royals) are. The blood from the sacrifice is poured onto the graves. Some of the meat is put on skewers and placed on the graves for Nananom Nsamanfo. The rest of the meat is added to that of the first sacrifice at Amanprobi for the preparation of the communal meal. This is a gift sacrifice to Nananom. It depicts communion between the living and Nananom Nsamanfo. Here the living share in a meal with Nananom Nsamanfo.

\section{b. Sacrifices during the washing of the Black stools of Okuapeman}

At dawn on Thursday, when the nkongua tuntum (black stools) of the state are taken to the Adami River to be washed, a sacrifice is made there. On this night, the nkongua tuntum from the Okuapehene ahenfie (Paramount chief's palace), as well as the other stool houses are sent to the Adami River and washed, and sacrifices are made so that there will be blood for washing these stools. All the houses do not take their stools at the same time. The first stool washed is that from the house of the Aboasahene (chief of the Aboasa quarter of Akropong). When it has been washed, a gunshot is given as a signal for the nkongua tuntum of the Okuapehene ahenfie to be taken into the river for washing. When the delegation from the Okuapehene ahenfie completes the washing, they also give a signal for the stool from the house next in line to be taken for washing. Each house gives a signal for the next house to bring its stool for washing. In this way, all the nkongua tuntum are taken, one house after the other and washed. A sheep is slaughtered by each house. The blood of the sheep is drained into the basin of water to be used for washing the stools. How the carcass is disposed of has not been disclosed to the author. ${ }^{22}$ The nkongua tuntum from the Okuapehene ahenfie represent Okuapeman. Cleansing them therefore signifies the cleansing of Okuapeman. The sacrifice involved could somehow point to a sacrifice of cleansing in which case, it could be said that the animal is sacrificed for purification to ensure that any $E f$ (ritual dirt) that may have come into Okuapeman is cleansed. Blood, in Akan thought, is a cleansing fluid. Thus, in any case of defilement, blood is required for cleansing. If murder is intentionally or accidentally committed, an animal would have to be sacrificed to take away the defilement. The sacrifice involved in this ritual cannot be placed under any of the categories discussed under types of sacrifices in this paper.

\section{c. Sacrifice in the stool rooms of the various stool houses}

That same Thursday, sheep are slaughtered in the various stool houses around mid-morning. The sheep in this sacrifice is stabbed in the neck by the head of the house. A few drops of blood fall on the floor of the nkonguadan (the room where the nkongua tuntum are kept). The stabbed animal is then carried through the yard of the house to the Bonsambo ${ }^{23}$ at the entrance of the house so that the blood from the animal drips onto the ground through the yard. The blood is drained out onto the Bonsambo. The carcass is returned into the yard and laid on a flat iron sheet. The legs are removed at the knees. Then the skin is removed, and the meat is cut up. This meat is used in preparing food for the household. Some of the meat is also put on skewers and roasted. These are placed on the nkongua tuntum of the houses. Each house does it for its akongua tuntum. The blood that drips through the yard cleanses and purifies the household. ${ }^{24}$ It is not a sacrifice for atonement but for cleansing. Though atonement may lead to cleansing, in this case, the idea of atonement does not come in. ${ }^{25}$ The blood that is poured on the bonsambo strengthens it and makes it powerful so that it can keep evil spirits

\footnotetext{
21 This is a place in the valley to the right on the way from Mamfe to Koforidua. It was the first place that the Akyem warriors who supported the Guan, the original occupants of the place where the Akuapem are today, in their war for liberation from the Akwamu.

22 This ritual is performed in the dead of the night and it is not allowed for others outside the assigned group to observe it.

23 A bonsambo is a ritual stone planted at the entrance of houses in which there are nkongua tuntum. Its purpose is to drive away evil spirits.

4 Interview with the Aboasahene on March 19, 2006.

Interview with Nana Kwasi Buor II on March 19, 2006.
} 
away from the house.

\section{d. Sacrifice to Odosu}

On this Thursday also, the Jmanhene presents an oguan $\mathbf{k J k J j}^{26}$ to the Odosu and it is sacrificed. The blood is poured over the Odosu..$^{27}$ The meat in this sacrifice is eaten by the priest of the Odosu alone. Whatever is left of it is buried in the ground. Odosu is the suman whose presence brought about the celebration of the festival in Akropong. The offering of the oguan kokso by Okuapehene to be sacrificed for it is significant. He presents it on behalf of the entire Okuapeman. The blood revitalises the power of the Odosu and seals the covenant between it and Okuapeman. It is an important aspect of the festival.

\section{e. Sacrifice at ahenfie nkonguadan mu}

On the evening of this Thursday, at a gathering of the chiefs of Okuapeman, a sheep is slaughtered upon the Ofori Kuma stool at the nkonguafie. The Ofori Kuma stool can be said to be the mother of all the Okuapeman stools. Some informants believe that the pouring of the blood of the sheep on the stool means cleansing Okuapeman as the authority of any Okuapehene is based on it. The blood of the sheep is drained upon this stool to signify the cleansing of the state. ${ }^{28}$ Other informants claim that this night, all the Divisional chiefs converge in Akropong and renew their oaths to the Ofori Kuma stool. The sheep is slaughtered, and its blood poured over the Ofori Kuma stool after the renewal of oaths. According to these informants, the sacrifice is meant to seal the oaths and not to cleanse Okuapeman.

\section{f. Sacrifice for Mpeni Kofi}

On Friday morning, there is another sacrifice made at the site of the tree known as Mpeni Kofi, which stands in the court in front of the palace of the Jmanhene. According to legend, the spirit of this tree watches over the town. In the night, it takes the form of a man and moves through the town watching over and protecting it. One elderly lady whose house is close to the site of the tree, a daughter of a man who used to be the ssofo (priest) of the tree said that many people who stayed out late encountered this spirit and it made them stop wandering about in the streets late into the night.

For this sacrifice, the priest of the Benkum Kyeame house slits the throat of the animal and drains the blood around the roots of the tree and onto the stones in front of the tree. Two men hold the slain animal by the fore and hind limbs and swing it sideways three times and then throw it away from the tree. It falls about two metres away from the tree. The men start working on the carcass. It is skinned and then the legs are cut off from the knees. The head, the stomach and bits of the intestines are placed in front of the tree. These are not cooked. The rest of the meat is cut up and cooked right on the site of the sacrifice.

This sacrifice resembles in many ways the Hebrew communion sacrifice. This is a gift sacrifice to Mpeni Kofi for taking care of the town through the year. The sacrifice is also meant to cleanse Mpeniase of all $E f$ and drive away any ahonhom bone (evil spirits) which may want to disturb the durbar which is held at the site later that day. ${ }^{29}$ In this sacrifice therefore there is an element of thanksgiving and cleansing.

These are some of the sacrifices that are made during the Odwira festival. Though they all involve the immolation of an animal, each is made for a different purpose. Akuapem Christians see these sacrifices as duplicating that of Christ, and yet not being able to achieve what the sacrifice of Christ does. To determine whether these claims are true or not, this paper now considers the sacrifice of Jesus Christ.

\section{The sacrifice of Christ}

According to Christian doctrine, when Adam and Eve ate the fruit that God had forbidden them to eat, sin entered the world and with it, death. Sin is defined several times in the Bible. In the Old Testament (OT), the Hebrew words hẽt' and hatta't are translated as sin. Literally, these words mean "to fail" or "to miss the mark". The verb 'awõn is also translated as sin in the OT. It means "to be distorted", to act perversely", or "to go astray". As a noun, it means "crime", "guilt", and "punishment". Pesha is also a Hebrew word translated as sin. It means "to rebel against someone" or "to revolt". Yet another Hebrew word translated as sin is shegãgãh, a noun derived from the verbs shagãh and shãgag. It means "to err". None of these can be said to be the exact equivalent of what the English word "sin" is. Sin is a disturbance of the relationship of Israel with God and so there had to be a way of re-establishing the lost community. This way was a sacrifice of propitiation or expiation, and in the Old Testament, an animal was used. ${ }^{30}$

\footnotetext{
26 Literally, oguan kokjo means red sheep, but it is a way of referring to a dog. Oguan kokoj is a dog.

27 This sacrifice is made in secret.

28 Interview with Nana Addo Dankwa III on October 12, 2004. Nana Kwasi Buor, the Aboasahene says that he is not aware of this sacrifice. Interview with Nana Kwasi Buor, March 19, 2006

29 Information on this sacrifice at Mpeniase was given by Nana Mossi Boateng, the Benkum Kyeame on Odwira Friday, September $18,2009$.

30 R. Mack, "The Main Aspects of Sin in the Old Testament", The Ghana Bulletin of Theology, 4, no.1, (1974), $1-8$.
} 
In the NT, the Greek opheilẽma (Hebrew: chob or choba) which has a root meaning of "debt" is translated as sin. Mack avers that the Hebrew word chob was the regular word for sin in late Judaism. The idea here is that human beings owe God a debt. Opheilẽma is used only once in the NT. ${ }^{31}$ The normal Greek word for sin in the NT is hamartia and means "missing the mark". There are other Greek words translated as sin in the NT. Some of these are planẽ, to stray, paraptõma, to fall aside or beside or, to stumble, parabasis, transgression, parakoẽ, disobedience, and, anomia, lawlessness. Though each of these words gives a different view of what constitutes sin, sin causes alienation from God. It is understood in relation to God, and in relation to humanity and society too as it breaks the harmonious relations within a society.

The teaching of the Christian faith is that God sent Jesus Christ to die so that human beings could be reconciled to God again. It is possible for forgiveness and restoration or fellowship with God to be obtained in and through the Lord Jesus Christ. ${ }^{32}$ The death of Christ which brings about this reconciliation is that which Akuapem Christians give as the reason why all other sacrifices have lost their relevance. It is the sacrifice that atoned for sin once and for all. Over the centuries of Christian history, theologians have tried to explain how this sacrifice brought about reconciliation.

Ekem discusses the views of some theologians on how the death of Christ has achieved reconciliation with God for humanity. ${ }^{33} \mathrm{He}$ observes that Clement of Rome and Ignatius of Antioch held the view that the blood of Christ which was poured out brought redemption to human beings. ${ }^{34}$ This means that the blood set humanity free from bondage to the power of sin; thus, because of the sacrifice, sin no longer has power over human beings. The shed blood brings forgiveness and hence, reconciliation. On the view of the writer of the Epistle of Barnabas, Ekem explains that having the understanding that Jesus suffered so that human beings might have healing through his wounds, Barnabas held that forgiveness of sins was achieved through the sprinkling of the blood of Christ. ${ }^{35}$ Going further, he says Justin Martyr emphasised that the blood of Christ purifies all who believe in Him. ${ }^{36}$ For Martyr then, the blood of Jesus is a cleansing fluid. Irenaeus on his part, thought in terms of human beings being enslaved by the powers of darkness; redemption is therefore freedom from these powers. The death of Jesus is the act that sets mankind free; by His blood, Christ has redeemed humanity. ${ }^{37}$

On Clement of Alexandria, Ekem points out that he argues that by His death, Jesus paid the debt of death which human beings were owing because of sin by giving Himself as a ransom..$^{38}$ Tertullian, he says, uses the word "satisfaction" to explain the atonement. He used this word for the penitential efforts of human beings, by way of doing good deeds, to satisfy God. According to Tertullian, Jesus Christ was sent to die, and that humankind's death could only be destroyed by the death of Christ.

Many other theologians including Anselm, Origen, Athanasius, and Augustine, have given their own understanding of the sacrifice of Christ. Morris avers that none of these have "won universal acceptance and it is probable that none ever will." He says further that the atoning work of Christ is too complex for the small minds of human beings to take in. The positive contributions of all the theories are needed, for each of them draws attention to some aspect of what Christ has done for humanity. ${ }^{39}$

\section{Odwira Sacrifices and the sacrifice of Christ}

One thing is clear from the discussion so far; through the sacrifice of Christ, mankind has been reconciled to God; through the sacrifice, the sins of mankind have been forgiven. It may therefore be called a sacrifice of propitiation, or expiation. The sacrifices of Odwira are not meant to right a broken relationship between the people and the supernatural beings to whom the sacrifices are made. They may be considered sacrifices to maintain the relationship between Okuapeman and the benevolent spiritual beings, but they are not for mending broken relationships. According to the Jmanhene Nana Addo Dankwa III, Akuapemfo do not see the sacrifices involved in Odwira as a means of "paying" for offences as the sacrifice of Christ has done. ${ }^{40}$ Christ's sacrifice was one of atonement.

In Twi, the word for atonement is mpata and it has to do with pacification or appeasement. When the community or an individual has incurred the wrath of a deity, this kind of sacrifice may be required. These are sacrifices usually prescribed by a deity to curb a crisis. ${ }^{41}$ The sacrifices in Odwira, Nana Addo Dankwa III says, are not for mpata (atonement). The blood of the animals is used together with other substances to bring about cleansing of objects like the

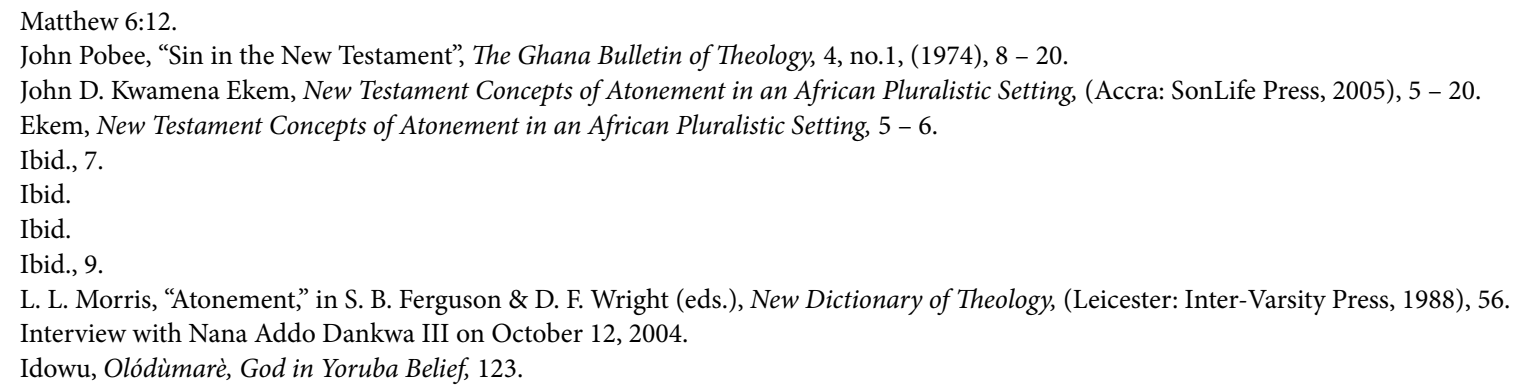


nkongua tuntum, ${ }^{42}$ or the whole sacrifice is a gift to Nananom Nsamanfo or a deity. The sacrifice made upon the Ofori Kuma stool on Odwira Thursday, he says, is meant to seal the vows made by the chiefs that evening, to remain loyal to the Ofori Kuma stool. The sacrifice made to Odosu, is also for sealing or renewing a covenant; None of the sacrifices discussed above has the element of mpata in it. ${ }^{43}$ None of them can therefore be compared to the sacrifice of Christ.

As already noted, in Christianity, the sacrifice of Christ has achieved forgiveness of sins, cleansing, reconciliation, and healing among other things, for humanity. Christians say that the blood of Jesus cleanses human beings from $\sin ^{44}$ It is a sacrifice which has removed every impediment that was standing in the way of human beings having a relationship with God. This is right. However, when Christian respondents say that because Christ has offered a sacrifice for sin, all blood sacrifices should cease, and that the blood sacrifices in the Odwira celebration are a challenge to the atoning work of Jesus, it must be clearly explained. The blood sacrifices in Odwira are not all meant for cleansing. Some of them are for giving thanks to Nananom Nsamanfo and abosom and therefore Onyankopon. Christians cannot say that these are wrong as Christ has not offered a once for all sacrifice of thanksgiving. Unless every blood sacrifice is meant for cleansing, or a blood sacrifice cannot be for thanksgiving, Christians cannot say that sacrifices must cease. A blood sacrifice in thanksgiving as seen in Leviticus 7:11-18, is not prohibited by the sacrifice of Christ. Commenting on this Nana Addo Dankwa III says:

...the use of blood for other purposes apart from sanctification does not cut across the basic principle of Christianity... The use of blood after the crucifixion of Christ has had very many conflicting interpretations but...Hebrews 9:12 and 10:14 clearly refer to sanctification, purification or anointing. The use of blood for any other purpose should not offend Christian principles. ${ }^{45}$

Sacrifices are made at $p$ w mu to Nananom Nsamanfo as a gift to them, to thank them for their help in the passing year, and to invite them to join the living to celebrate Odwira. This sacrifice is not one for cleansing or purification. While sacrifices made during Odwira for cleansing may not be necessary, the same cannot be said for those for thanksgiving. Christians bring thank-offerings to their worship for recovering from sickness or surviving a calamity or some other favour shown by God. For example, as part of the announcements made in congregations of the Presbyterian Church of Ghana (PCG) every Sunday, voluntary thank-offerings of members are mentioned. These are not blood sacrifices, but the essence is the same. The sacrifice of Christ is not a thank-offering. It therefore cannot be said to have cancelled thank-offerings made with the blood of animals. In the light of this, the sacrifices of Odwira do not challenge that of Jesus Christ. They cannot therefore be conflicting with the Christian faith. However, considering who the sacrifices are meant for, the conflict of these sacrifices with the Christian faith, becomes clear.

Gift offerings to Nananom Nsamanfo and to the Mpeni Kofi conflict with Christianity. The offering of gifts to Nananom Nsamanfo may be said to be a sign of reverence and not worship. What is wrong with making a blood sacrifice to Nananom Nsamanfo as a gift of appreciation? This is a difficult question to answer. Strathmann makes comments on the Greek word latreuen which has to do with service or worship and connects it with sacrifice. According to him, latreuen has sacral significance. He says that "it means more precisely, to serve or worship (the gods) cultically, especially in sacrifice." 46 Sacrifices signify worship where spirit beings are concerned. While it may be argued that it has to do with showing reverence to Nananom Nsamanfo, going by what Srathmann says, it is a sign that they are worshipped. Not only that, they are also believed to mediate between Onyankopon/Onyame, and human beings. Jesus Christ has however, rendered the mediatory role of all other supernatural beings obsolete; this is made clear in the Letter to the Hebrews. ${ }^{47}$ There is only one mediator between God and men, and that is Jesus Christ. ${ }^{48}$ There is therefore no need to offer any gifts to Nananom Nsamanfo and abosom.

There is also no need to offer gifts to Mpeni Kofi who is a bosom, Akuapemfo have no business giving him gifts in whatever form. Continuing to do so is saying that he is still positively relevant to Okuapeman. The word "positive" is used to describe "relevant" because in the history of traditional Akuapem spirituality Mpeni Kofi is relevant. It is part of the "Old Testament" of Akuapemfo. Its usefulness has however ceased, and to continue to sacrifice to it is to say that it still is an intermediary spirit for Akuapemfo. The sacrifice to Mpeni Kofi during Odwira may not be for atonement but it still conflicts with the Christian faith.

Sacrifices have a place in Christianity for the faith is based on a sacrifice - the sacrifice of Jesus Christ. It is who sacrifices are meant for that determine whether something that conflicts with Christian faith is being done or not. As

42 Interview with Nana Addo Dankwa on October 12, 2004.

43 Interview with Jkoman Panyin Akyeampong in 2001 at his house in the Aboasa Quarter of Akropong. He was surprised that anyone would think of Odwira in terms of mpata.

$44 \quad$ I John 1:7.

45 Oseadeeyo Addo Dankwa III, The Institution of Chieftaincy in Ghana - The Future, (Accra: Konrad Aenauer Foundation, 2004$)$, 75.

46 Strathmann, Theological Dictionary of the New Testament (vol. IV), (Grand Rapids, Michigan: Wm B. Eerdmans Publishing Co.,1967), 60.

47 Hebrews 10:

$48 \quad 1$ Timothy 2:5. 
already mentioned, De Vaux writes concerning sacrifice,

It is the essential act of external worship. It is a prayer which is acted, a symbolic action which expresses both the interior feelings of the person offering it, and God's answer to his prayer. ${ }^{49}$

A person who makes a sacrifice therefore engages in an external act of worship. It is what the person feels internally, within, that is expressed symbolically in the sacrifice. Idowu posits that sacrifice is the best way for human beings to maintain an established relationship with their object of worship..$^{50}$ This is the crux of the matter. Any sacrifice made is an act of worship. When sacrifice is made to any supernatural being for whatever purpose, that spirit is worshipped and that is against the command of Yahweh and thus conflicts with the Christian faith. While it is said that sacrifices made to deities are ultimately meant for the Supreme Being, God, it must be accepted that with the sacrifice made by Christ, there is now no need for any other intermediaries between God and humanity apart from Christ.

\section{The sacrifice of Christ and Akan world view}

The Akan see the world as one full of wicked spirits from which human beings must be protected, and this is the object of their religious rituals. They believe that protection from the ahonhommone (malevolent spirits), which populate the universe comes from the ahonhom papa (benevolent spirits), which include the abosom and Nananom Nsamanfo. It is to these benevolent spirits that the Akan make sacrifices in thanksgiving and for pacification to ensure good relations with them so that they can have their protection. Thus, even though the sacrifices for Odwira may not be for protection, they are, for they are all meant to gladden the benevolent spirits and to ensure that the community is in their good books. The sacrifices in Odwira ensure that Okuapeman continues to enjoy the protection of the benevolent spirits from the activities of malevolent spirits against them. To say that because of the sacrifice of Christ, they do not need to offer sacrifices to the ahonhom papa again, one must be able to show that without the sacrifices they will still be protected from the ahonhommone. This calls for a look at the benefits of the sacrifice of Christ in addition to forgiveness and reconciliation.

\section{The sacrifice of Christ makes us children of God}

In John 1: 12, the writer of the gospel, notes that the "Word", Jesus, gives anyone who believes in Him the power to become a child of God. Calvin takes the word "authority" or "power" to mean an honour. ${ }^{51}$ He explains that when the John says Christ gives those who believe in the name of Jesus the authority to become children of God, it does not mean that believers may choose to use the authority to become children of God, or reject it. He argues that the context does not allow the "paltry quibbling over one word". He goes on to draw attention to the fact that John adds that believers "become the sons of God, not by the will of the flesh but by being born of God". He continues,

For if faith regenerates us so that we are the sons of God, and if God breathes faith into us from heaven, the grace of adoption offered to us by Christ is obviously not only potential but actual... ${ }^{52}$

Those who believe in the name of Jesus Christ become children of God! This is what John captures in John 1: 12. The passage puts a special relationship between those who believe in Jesus and God; it is a familial relationship. All who believe in Jesus are heirs of God as they are joint heirs of God with Christ. This means that they receive the "birthright to all the blessings and privileges which" the coming of Christ was designed to impart. ${ }^{53}$ Thus in the letter to the Ephesians, Paul says of believers:

So then, you are no longer strangers and sojourners but fellow citizens with the saints and members of the household of God....

Paul's words to these Gentile Christians show how faith in Christ has led to a change in their status and position so that they are not strangers and sojourners in God's kingdom but members of God's household, just like all other believers in Christ. Commenting on this verse, Barth says:

That man is under God's protection who submits to Israel's king and becomes a citizen of Israel. He is not only a citizen of an earthly city or state but a "member of God's household". God cares for him as a father does for his children. ${ }^{55}$

Believers are people of God's household, they are family. God himself takes care of them because He is their father. He protects them, provides for them, and guides them. It is therefore no wonder that Paul says that they have been rescued

49 De Vaux, Ancient Israel Its Life and Institutions, 451.

50 Idowu, Olódùmarè: God in Yoruba Belief, 118.

51 T. H. L. Parker, Calvin's Commentaries: The Gospel according to St John 1 - 10, (Grand Rapids, Michigan: William B. Eerdmann's Publishing Company, 1961 ), 17.

52 John Calvin, Calvin's Commentaries, 17.

53 Frederick. F. Bruce, The Gospel of John, (Basingstoke, Hants: Pickering \& Inglis, 1983), 38.

54 Ephesians 2: 19 (RSV).

55 Markus Barth, The Anchor Bible: Ephesians, Introduction, Translation, and Commentary on Chapters 1 - 3, (Garden City, New York: Doubleday \& Company Inc., 1980), 270. 
from the dominion of darkness and brought into the kingdom of God's dear son. ${ }^{56}$ Commenting on this, Stott writes, In every true conversion there is a turning not only from sin to Christ, but 'from darkness to light', 'from the power of Satan to God', and 'from idols to serve the living and true God'; there is also a rescue from the dominion of darkness... into the kingdom of the Son God loves..$^{57}$

Darkness here refers to the ahonhommone. A Christian, through conversion, has been delivered from the authority of ahonhommone so that they do not have power over the believer again; their authority in the lives of believers is broken. The transfer from the kingdom of darkness into the kingdom of Christ, the Son God loves, means that the believer in Christ does not need to make sacrifices to ahonhom papa for protection from the ahonhommone. The sacrifice of Christ thus renders such sacrifices unnecessary. A Christian who engages in them gives the message that $\mathrm{s} / \mathrm{he}$ does not believe in this rescue and transfer.

The Bible also reveals that in the sacrifice of Christ, ahonhommone have been conquered. In his book, Christus Victor, Aulen, argues that in the sacrifice of Christ, evil was conquered. Stott says of Aulen's view on the sacrifice of Christ, ...Gustav Aulen was right to draw the church's attention to the cross as victory, and to show that by his death Jesus saved us not only from sin and guilt, but from death and the devil, in fact all evil powers as well. ${ }^{58}$

Colossians 2: 15 affirms Aulen's view. Paul here informs his readers that Jesus disarmed the devil and all his "principalities and powers" and triumphed over them. Harris in his Exegetical Guide to the Greek New Testament works around the Greek text and translates the verse as:

And after disarming the powers and authorities, he boldly displayed them in public by leading them in triumphal procession through Christ. ${ }^{59}$

and gives an expanded paraphrase of it as:

What is more, after he had rendered the powers and authorities helpless, he boldly exposed them to public display when, through Christ's death, he led them in his triumphal procession as his enemy captives. ${ }^{60}$

Going by Harris' translations, God has, in the sacrifice of Christ rendered the powers and authorities powerless, He has disarmed them and publicly displayed His triumph over them. The issue however is with what Paul means by "principalities and powers" or "powers and authorities". There has been some argument on whether the "powers and authorities", translated in the Revised Standard Version (RSV) of the Bible as "principalities and powers" refer to evil spirits or to structures of earthly power and existence. While the title "King of Kings" for Jesus places Him within the structures of earthly existence and power and could make one see the "principalities and powers" used by Paul here as being in relation to political powers, Stott says we must also consider the fact that Paul mentions these same "principalities and powers" in Ephesians 1: 21 and Ephesians 6: 12. In Ephesians 1: 21, Paul says,

...far above all rule and authority, power and dominion, and every title that can be given, not only in the present age but also in the one to come. ${ }^{61}$

In this verse, Paul talks about the authority and power that God has given to the Lord Jesus Christ. It is not clear whether the words "rule and authority, power and dominion" refer to physical political structures or spiritual ones. It is even more difficult to think of what these words refer to in the Twi Bible. In Twi, mpaninnie, tumidie, do not refer to evil spirits but to physical structures. Evil spirits are often referred to as esum-mu-atumfos or abayifo or ahonhommone.

Bible scholars like Berkhof, ${ }^{62}$ Caird, ${ }^{63}$ Carr $^{64}$ Schlier, ${ }^{65}$ Wink $^{66}$ and Cullmann ${ }^{67}$ have done research on Paul's usage of the words "principalities and powers" which are shorthand for terms Paul uses for powers that God created but which are somehow hostile to Jesus Christ and His church. Writing on the topic "Principalities and Powers", Reid says Bultmann, working from an existential approach saw what Paul referred to as powers as mythic projections of the disease

\footnotetext{
See Colossians 1: 13 - 14 .

John Stott, The Cross of Christ, (Leicester: Inter-Varsity Press, 1991), 236.

Stott, The Cross of Christ, 229.

59 Murray J. Harris, Exegetical Guide to the Greek New Testament, Colossians \& Philemon, (Grand Rapids, Michigan: Wm. B. Eerdmans Publishing Company, 1991), 112.

60 Ibid., 113

61 Ephesians 1: 21 (NIV)

62 Hendrik Berkhof, Christ and the Powers, tr. J. H. Yoder, (Scottdale, PA: Herald, 1977).

63 George. B. Caird, Principalities and Powers: A Study in Pauline Theology, (Oxford: Claredon, 1956).

${ }^{64}$ Wesley Carr, Angels and Principalities: The Background, Meaning and Development of the Pauline Phrase "hai archai kai hai ...exousiai", (Cambridge: Cambridge University, 1981).

65 H. Schlier, Principalities and Powers in the New Testament, (New York: Herder, 1961).

66 W. Wink, Unmasking the Powers: The Invisible Powers that Determine Human Existence, (Philadelphia: Fortress, 1986).

67 Oscar Cullmann, The State in the New Testament, (London: SCM, 1975).
} 
of human beings within the cosmos. Cullman, working on the word "power" in Romans 13 and I Corinthians 2: $6-8$, saw powers as referring to both spiritual and civil authorities. He did his work in the European context soon after the Second World War. Berkhof also arrived at the conclusion that Paul demythologised the powers and used the language to refer to the structures of earthly existence, for example, tradition, morality, justice, and order. This view has been adapted by others. These people argue that Paul was referring to both the socio-political structures of society and the spiritual forces behind and within those structures.

The one who has done the most comprehensive study on the subject is Wink. His conclusion is that Paul uses 'power to refer simultaneously to the "inner and outer aspects of any given manifestation of power"'. According to him, Paul believed in the ontological reality of an invisible spirit world. He further posits that Paul had already taken steps toward demythologizing that world view. This is seen in the fact that he expanded the list of enemies of Christ and His people to include sin, death, flesh, and Law. For Wink, the powers are "both heavenly and earthly, divine and human, spiritual and political, invisible and structural". For this reason, in the plan of God for cosmic restitution, they can be "depotentiated" and "neutralised"; they can even be redeemed. ${ }^{68}$

Commenting on Colossians 2: 15, Stott says, without mincing words, that the "principalities and powers" above which Jesus has been exalted are demons. ${ }^{69}$ When Paul uses the same words in Ephesians chapter 6, he begins in a way that makes it clear that he is referring to wicked spiritual beings. This is because he starts by saying, "For our struggle is not against flesh and blood....” Paul lets his readers know that the fight or struggle that they are engaged in is not a physical one. He then goes on to mention who Christians are struggling with. He says the struggle is against the rulers, authorities, the powers of this dark world, and the spiritual forces of evil in the heavenly realms. Is Paul talking here about the same things that he uses the words to refer to in Ephesians 1: 21 and Col 2: 15? This is an important question for in these passages, Jesus has authority over the powers and authorities, and with Him, believers also have authority over them. If what Paul refers to as "rulers, authorities, powers of this dark world" in Ephesians 1: 21 and Colossians 2: 15 refer to physical structures, and are the same as those in Ephesians 6: 12, why does Paul say here that believers are fighting against things they cannot see and must therefore wear the "whole armour of God"? Clearly, those words do not refer just to physical structures, but to spiritual ones too. The "armour" that Paul describes has to do with what Christ has done for humanity. Paul therefore asks believers to put on Christ, appropriate His work on the cross and His victory too. Jesus has conquered the ahonhommone and esum-mu-atumfoo.

Explaining why although Christ has defeated the evil forces Christians still have to fight him, Stott posits that even though Jesus has defeated the devil, the latter has not conceded defeat yet; the devil has been overthrown, but he has not been eliminated yet. ${ }^{71}$ This however does not mean that Christ has not conquered Satan and all his forces, He has, and the believer who remains in Christ by wearing the whole armour of God is protected from all these ahonhommone. The sacrifice of Christ which has reconciled the believer to God, has also defeated all the forces of darkness. The Akan Christian does not need to sacrifice to any spirits for protection from ahonhommone. The reasons for which the Akan has ever needed to make sacrifices has been met in Christ's sacrifice. Therefore, these sacrifices are no longer necessary.

\section{RECOMMENDATION}

From the foregoing, the Akuapem Christian does not need sacrifices any more after that of Jesus Christ. While this is true, the celebration of the Odwira festival does not have to end. It is not all about the sacrifices. As a festival, it is important for everyone who comes from Akuapem; it serves a good purpose in their lives. People who are indigenes of Akuapem must not stay away from the celebration of the festival just because they are Christians. They must go to Akuapem for the celebration whenever it is possible. Odwira is more than the sacrifices. Christians may celebrate without sacrifices as according to the finding of this paper the sacrifice of Christ has rendered all other sacrifices irrelevant, the sacrifices of Odwira included. This may not be appreciated by those who do not believe in Jesus Christ and they may want to continue celebrating it with the sacrifices. Such people need not be forced to give up their sacrifices. The Church in Akuapem must come together and plan activities for the festival time that promote the heritage and culture of the people. These activities must focus on making the younger generation get to know the legends and traditions of their people. The recommendation of this paper is that Akuapem Christians should gather in their towns during Odwira and celebrate the relevant parts, socialising with one another and with the other townspeople. They may have outdoor programmes where they would explain what the sacrifice of Jesus means for the Akuapem people, and why sacrifices are no longer necessary in the celebration of Odwira. The fact that Jesus offered Himself as a sacrifice to cleanse the world of all sin, all pollution, should be emphasised by the Church. This will be meaningful given that the name of the festival, Odwira,

\footnotetext{
68 Daniel G. Reid, "Principalities and Powers", in Gerald F. Hawthorne, Ralph P. Martin, Daniel G. Reid (Eds), Dictionary of Paul and his Letters, (Leicester, England: InterVarsity Press, 1993), 746 - 748.

69 John R. W. Stott, The Message of Ephesians, (USA: Inter-Varsity Press, 1979), 60.

70 Ephesians 6: 12a (NIV).

${ }^{71}$ Stott, The Cross of Christ, 239.
} 
means "cleansing" or "purification". In the Twi Bible, a part of Hebrews 1:3 reads: “...na ode n'ankasa ne ho dwiraa yen bone no..." "'2, referring to the fact that Jesus has purified the world by His sacrifice. The festival is meant to be for purification of the Akuapem state and its people; this, Jesus Christ has accomplished through His sacrifice, the ultimate sacrifice. The significance of the festival has been achieved in Christ's sacrifice. Thus, Christians may celebrate Odwira as a celebration of the accomplished work of Christ without any personal conflicts.

\section{CONCLUSION}

In the traditional celebration of Odwira, sacrifices are made in some of its aspects. These sacrifices are basically gifts and thank-offerings, and not meant for atonement. They are made to ensure that good relations are maintained between the people and the ahonhom papa so they can always enjoy their services as mediators and their protection from the activities of the ahonhommone. Some are also made to renew or seal vows and covenants. However, in the light of the mediatorial role of Jesus, that of the ahonhom papa has been rendered obsolete. There is thus no reason to keep treating them as mediators. Also, because Jesus Christ in His sacrifice has overcome the ahonhommone, the esum-mu-atumfo, the abayifo, believers do not need the benevolent spirits to protect them anymore. Making sacrifices to them will constitute continued dependence on them for protection; it will be choosing an inferior protection over a superior one. Akuapem Christians therefore have a point in saying that the sacrifices in Odwira are no longer necessary. Christians must rather appropriate the sacrifice of Christ and its benefits and live in victory over the forces of evil. Akuapem Christians must however not stay away from celebrating the festival but interpret the cleansing power of Christ's sacrifice in terms of the purpose of Odwira, purification of the people, and use the celebration to make Akuapem Christians, and all other Akuapem people, appreciate what the sacrifice of Christ means for them.

\section{ABOUT AUTHOR}

Ernestina Afriyie (PhD), is a Research Fellow, Akrofi-Christaller Institute of Theology, Mission and Culture, AkropongAkuapem. She has research interests in World Christianity, with focus on African Christianity, engaging traditional or indigenous cultures with the Gospel.

\section{BIBLIOGRAPHY}

Addo Dankwa III, Oseadeeyo, The Institution of Chieftaincy in Ghana - The Future, (Accra: Konrad Aenauer Foundation, 2004).

Barth, Markus, The Anchor Bible: Ephesians, Introduction, Translation, and Commentary on Chapters 1 - 3 (Garden City, New York: Doubleday \& Company Inc., 1980).

Berkhof, H., Christ and the Powers, tr. J. H. Yoder, (Scottdale, PA: Herald, 1977).

Bruce, F. F., The Gospel of John, (Basingstoke, Hants: Pickering \& Inglis, 1983).

Caird, G. B., Principalities and Powers: A Study in Pauline Theology, (Oxford: Claredon, 1956).

Carr, W., Angels and Principalities: The Background, Meaning and Development of the Pauline Phrase "hai archai kai hai ...exousiai", (Cambridge: Cambridge University, 1981). https://doi.org/10.1017/cbo9780511554896

Cullmann, O., The State in the New Testament, (London: SCM, 1975).

De Vaux, Roland, Ancient Israel Its Life and Institutions, (London: Darton, Longman \& Todd, 1978).

Der, B. G., "God and Sacrifice in the Traditional Religions of the Kasena and Dagaba of Northern Ghana," Journal of Religion in Africa, XI, 3, (1980), 172 - 187. https://doi.org/10.1163/157006680x00124

Ekem, John D. Kwamena, New Testament Concepts of Atonement in an African Pluralistic Setting, (Accra, Ghana: SonLife Press, 2005).

Gaba, C. R., "Sacrifice in Aylo Religion, Part I," The Ghana Bulletin of Theology, 3, no.5, (1968), 13 - 19.

Harris, Murray J., Exegetical Guide to the Greek New Testament, Colossians \& Philemon, (Grand Rapids, Michigan: Wm. B. Eerdmans Publishing Company, 1991).

Hastings, James (Ed.), Encyclopedia of Religion and Ethics vol 11, (Edinburgh: T. \& T. Clark Ltd, 1980).

Idowu, E. Bolaji, Olódùmarè, God in African Belief, (Brooklyn, New York: A\&B Books Publishers, 1994).

Mack, R., "The Main Aspects of Sin in the Old Testament", The Ghana Bulletin of Theology, 4, no. 1, (December 1974), $1-8$.

Mbiti, John S., African Religions and Philosophy, (Oxford: Heinemann, 1990).

Morris, L. L., "Atonement," in S. B. Ferguson \& D. F. Wright (eds.), New Dictionary of Theology, (Leicester: Inter-Varsity Press, 1988).

\footnotetext{
72 Hebrews 1: 3, “... after making purification for sins...”
} 
Olowola, Cornelius, "Sacrifice in African Tradition and in Biblical Perspective", Africa Journal of Evangelical Theology, 10, 1, (1991), 5.

Parker, T. H. L., Calvin's Commentaries: The Gospel according to St John 1 - 10, (Grand Rapids, Michigan:William B. Eerdmann's Publishing Company, 1961).

Pobee, J. "Sin in the New Testament", The Ghana Bulletin of Theology, 4, no.1, (December 1974), 8 - 20.

Reid, Daniel G., "Principalities and Powers", in Gerald F. Hawthorne, Ralph P. Martin, Daniel G. Reid (Eds), Dictionary of Paul and his Letters, (Leicester, England: InterVarsity Press, 1993).

Schlier, H., Principalities and Powers in the New Testament, (New York: Herder, 1961).

Stott, John R. W., The Message of Ephesians, (USA: Inter-Varsity Press, 1979).

Stott, John, The Cross of Christ, (Leicester: Inter-Varsity Press, 1991).

Strathmann, in Theological Dictionary of the New Testament (vol. IV), (Grand Rapids, Michigan: Wm B. Eerdmans Publishing Co.,1967).

Ukpong, Justin S., "The Problem of God and Sacrifice in African Traditional Religion," Journal of Religion in Africa, XIV, fasc 3, (1983), 187 - 203. https://doi.org/10.1163/157006683x00077

Wink, W., Unmasking the Powers: The Invisible Powers that Determine Human Existence, (Philadelphia: Fortress, 1986). 